\title{
SISTEM PENDUKUNG KEPUTUSAN PEMBERIAN KREDIT MOBIL DENGAN FUZZY TSUKAMOTO(STUDI KASUS : PT CLIPAN FINANCE)
}

\author{
Daniel Prasetyo Tarigan'), Agus Wantoro $^{2)}$, Setiawansyah ${ }^{3)}$

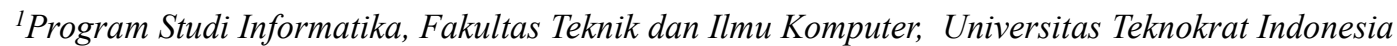 \\ ${ }^{2}$ Program Studi Sistem Informasi, Fakultas Teknik dan Ilmu Komputer, Universitas Teknokrat Indonesia \\ ${ }^{3}$ Program Studi Informatika, Fakultas Teknik dan Ilmu Komputer, Universitas Teknokrat Indonesia \\ Jl.H. Zaenal Abidin Pagaralam no. 9-11 Labuhan Ratu, Bandarlampung \\ Email: '1aniel.prastyo16@gmail.com, ${ }^{2}$ aguswantoro@teknokrat.ac.id, ${ }^{3}$ setiawansyah@teknokrat.ac.id,
}

\begin{abstract}
Abstrak
Penelitian ini dilakukan atas dasar kebutuhan akan adanya sistem yang dapat menghitung batas kemampuan bayar pemohon kredit. Dengan sistem ini diharapkan credit analyst dapat lebih cepat dan tepat lagi dalam memberikan hasil analisa rekomendasi pemohon kredit agar tidak terjadi kredit macet yang dapat merugikan PT Clipan Finance. Sistem ini tidak memiliki keterkaitan dengan harga mobil ataupun lamanya angsuran. Sistem pendukung keputusan ini menggunakan metode Fuzzy Tsukamato, variabel yang ditetapkan pada sistem pendukung keputusan ini adalah pendapatan, pengeluaran, jarak, usia sedangkan angsuran merupakan nilai output dari sistem pendukung keputusan ini. Hasil output dari sistem pendukung keputusan ini adalah batas nilai maksimal angsuran yang dapat dibayarkan oleh debitur, hasil ini merupakan hasil yang dapat membantu credit analyst untuk memberikan rekomendasi yang tepat yang selanjutnya apakah permohonan kredit dapat diterima atau tidak ditentukan oleh keputusan akhir dari Branch Manager.
\end{abstract}

Kata Kunci: Fuzzy Tsukamoto, variabel, Credit Analyst, Branch Manager, Pemohon Kredit

\section{Pendahuluan}

\subsection{Latar Belakang}

PT Clipan Finance merupakan salah satu perusahaan leasing yang memberikan jasa pembiayaan konsumen khususnya pembiayaan kredit mobil. Salah satu yang menjadi kendala bagi perusahaan leasing khususnya PT Clipan Finance adalah kredit macet. Kredit macet adalah keadaan dimana konsumen kredit sudah tidak sanggup membayar pokok pinjaman dan pembayaran bunganya terdapat tunggakan telah melampaui 270 hari (Surat Keputusan Direksi Bank Indonesia No 32/268/KEP/DIR). Kredit macet merupakan penghambat laju perkembangan perusahaan dan menyebabkan kerugian sehingga perlu dilakukan seleksi yang tepat berdasarkan analisis data pemohon kredit.
Credit Analyst yang bertugas untuk melakukan analisis terhadap kemampuan membayar pemohon kredit Banyaknya pemohon yang mengajukan kredit dengan kondisi ekonomi yang berbeda beda menuntut Credit Analyst memiliki kejelian dalam mengambil keputusan, sehingga Credit Analyst memiliki peranan penting untuk meminimalisir kasus kredit macet yang terjadi di perusahaan yang bisa menyebabkan kerugian pada perusahaan. Oleh Karena itu, untuk membantu Credit Analyst dalam memberi rekomendasi keputusan diperlukan suatu sistem pendukung keputusan yang dapat menghitung batas kemampuan bayar pemohon kredit sehingga membantu Credit Analyst dalam proses analisa data pemohon kredit berdasarkan faktor - faktor yang menjadi acuan

Dari permasalahan yang telah disampaikan di atas dibutuhkan adanya sebuah sistem yang mampu memprediksi batas kemampuan bayar pemohon kredit sehingga membantu Credit Analyst dalam memberikan rekomendasi keputusan penerimaan kredit mobil berdasarkan hasil perhitungan. Maka mahasiswa membuat sebuah sistem Pendukung Keputusan penerimaan kredit mobil dengan menggunakan Fuzzy Logic yang diharapkan sistem ini dapat menghitung batas kemampuan membayar angsuran pemohon kredit sehingga membantu Credyt Analyst untuk memberikan rekomendasi keputusan secara tepat, akurat dan logis

\subsection{Landasan Teori}

Penelitian - penelitian yang dilakukan sebelumnya yaitu [1] bahwa metode Fuzzy Tsukamoto berhasil diterapkan untuk membantu menentukan kelayakan warga penerima JAMKESMAS. Serta penelitian [2] melakukan penelitian bagaimana memilih kredit kepemilikan rumah yang sesuai menggunakan metode Fuzzy Tsukamoto dengan menggunakan variabel variabel antara lain pengeluaran, pemasukan dan angsuran

\section{Kredit dan Kredit Analis}

Kredit berasal dari bahasa Yunani Credere yang berarti kepercayaan, oleh karena itu dasar dari kredit adalah kepercayaan [3] Menurut Pasal 1 Angka 11 UndangUndang Perbankan yang dimaksud kredit adalah 
penyediaan uang atau tagihan yang dapat dipersamakan dengan itu, berdasarkan persetujuan atau kesepakatan pinjam meminjam antara bank dengan pihak lain yang mewajibkan pihak peminjam untuk melunasi hutangnya setelah jangan waktu tertentu setelah member bunga.

Kredit Analis adalah seseorang yang menganalisis semacam studi kelayakan (feasibility) atas perorangan atau perusahaan pemohon kredit. dalam praktiknya setiap pemberian kredit wajib melakukan penilaian dari berbagai aspek meliputi [4] : Character, Capacity, Capital, Collateral, Capacity

\section{Kriteria Kelayakan}

Kelayakan yang ditentukan oleh perusahaan pembiayaan terutama meliputi beberapa variabel dimana mempunyai saling keterkaitan untuk mendukung apakah pemohon tersebut layak atau tidak diberikan kredit kriteria tersebut yaitu pendapatan, pengeluaran, jarak, usia serta angsuran.

\section{Representasi Linier}

Representasi Linier Naik yaitu kenaikan himpunan dimulai pada nilai domain yang memiliki derajat keanggotaan nol (0) bergerak ke kanan menuju ke nilai domain yang memiliki derajat dan Representasi Linier Turun yaitu garis lurus dimulai dari nilai domain dengan derajat keanggotaan tertinggi pada sisi kiri [5].

4. Use Case
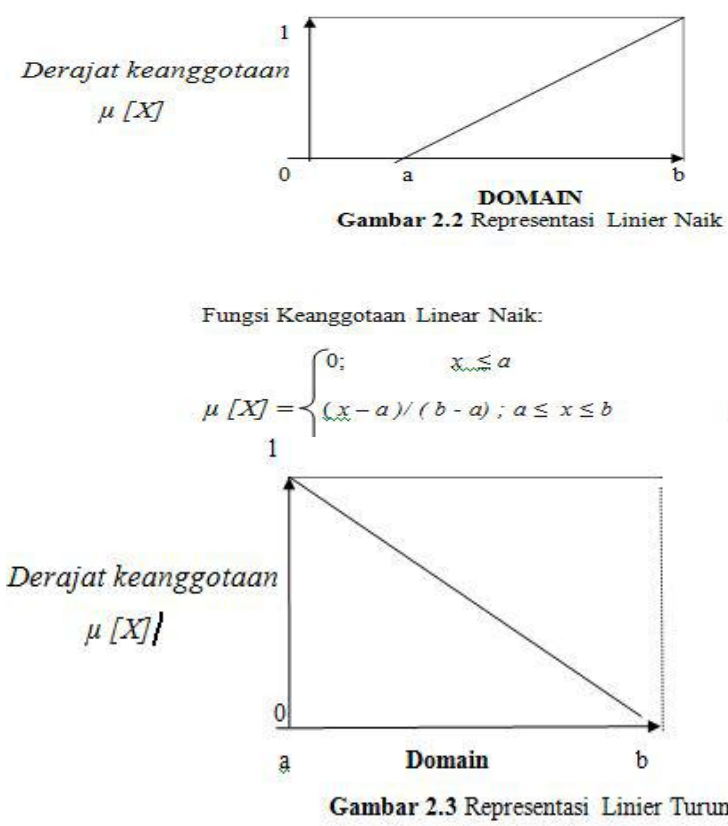

Fungsi Keanggotaan Linier Turun.

$$
\mu[X]= \begin{cases}(b-x) /(b-a) ; a \leq x \leq b \\ 0 ; & x \geq b\end{cases}
$$

Use Case Diagram merupakan pemodelan untuk mendeskripsikan sebuah interaksi antara satu atau lebih aktor dengan sistem informasi yang akan dibuat. Secara garis besar, use case digunakan untuk mengetahui fungsi apa saja yang ada di dalam sebuah sistem informasi dan siapa saja yang berhak menggunakan fungsi-fungsi [6]. Pada penelitian ini menggunakan aktor dan tabel use case

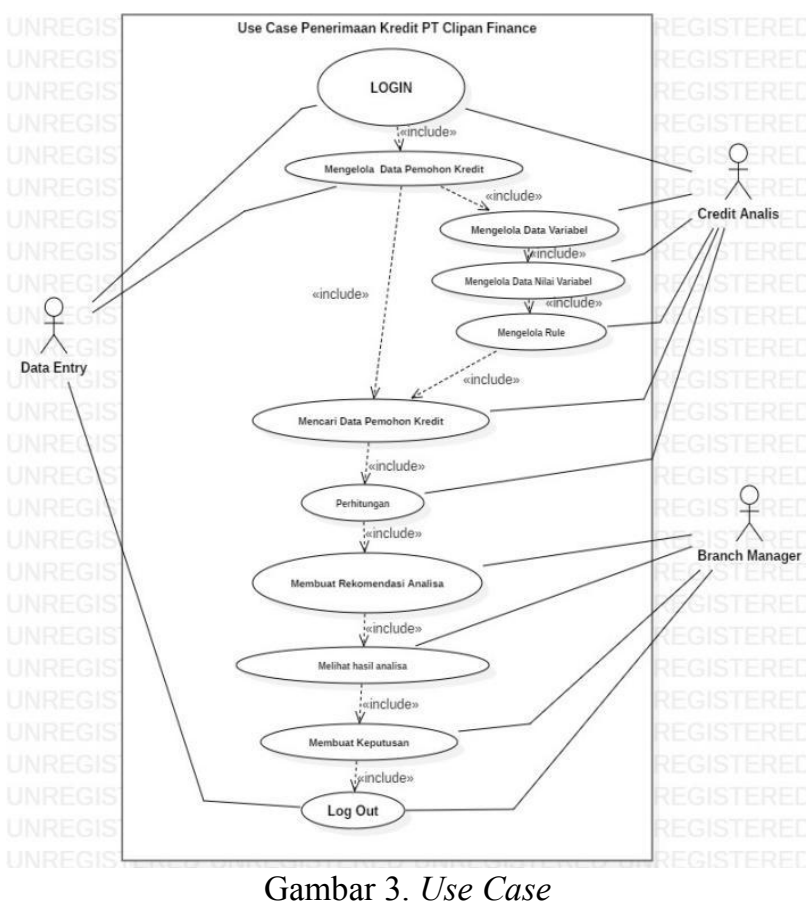

\section{Metodologi Penelitian}

Penerapan Fuzzy Tsukamoto pada penelitian ini adalah menentukan berapa besaran angsuran yang didapat sebagai Pendukung keputusan penerimaan kredit. Untuk menentukan berapa nilai angsuran yang digunakan tiga variabel yaitu Pendapatan, Pengeluaran, dan Jarak sebagai parameter perhitungan. Berikut ini adalah tabel variabel dan nilai variable.

\begin{tabular}{|c|c|c|}
\hline Variabel & Keterangan & Nilai \\
\hline \multirow{3}{*}{ PENDAPATAN } & TINGGI & Rp $15.000 .000-R p 25.000 .000$ \\
\hline & SEDANG & $\operatorname{Rp} 10.000 .000-\operatorname{Rp} 20.000 .000$ \\
\hline & RENDAH & $\operatorname{Rp} 5.000 .000-\operatorname{Rp} 15.000 .000$ \\
\hline \multirow{3}{*}{ PENGELUARAN } & TINGGI & Rp $4.000 .000-\operatorname{Rp} 6.000 .000$ \\
\hline & SEDANG & $\operatorname{Rp} 3.000 .000-\operatorname{Rp} 5000.000$ \\
\hline & RENDAH & $\operatorname{Rp} 2.000 .000-\operatorname{Rp} 4000.000$ \\
\hline \multirow{3}{*}{ JARAK } & JAUH & $60 \mathrm{KM}-100 \mathrm{KM}$ \\
\hline & SEDANG & $40 \mathrm{KM}-80 \mathrm{KM}$ \\
\hline & DEKAT & $20 \mathrm{KM}-60 \mathrm{KM}$ \\
\hline \multirow{3}{*}{ USIA } & MUDA & 18 TAHUN - 40 TAHUN \\
\hline & DEWASA & 30 TAHUN - 50 TAHUN \\
\hline & TUA & 40 TAHUN - 65 TAHUN \\
\hline \multirow{2}{*}{ ANGSURAN } & TINGGI & Rp 4.000 .000 \\
\hline & RENDAH & Rp 1.000 .000 \\
\hline
\end{tabular}

\subsection{Variabel Pendapatan}

Variabel pendapatan merupakan variabel pemasukan atau gaji yang di dapat oleh pemohon kredit. Dalam hal 
ini besaran pendapatan yang di dapat pemohon kredit dinilai berdasarkan rentan waktu 30 hari (1 bulan). Variabel pendapatan dibagi menjadi tiga himpunan yaitu Rendah, Sedang, dan Tinggi.

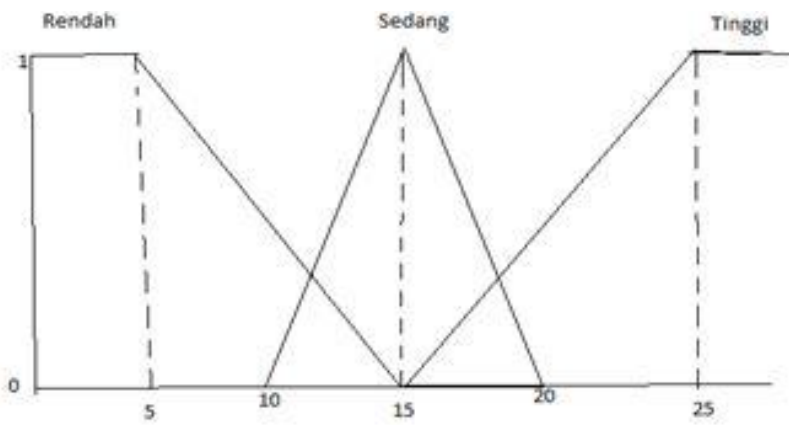

Gambar 3.1 Variabel Pendapatan

( $\mu$ Pendapatan Rendah) :

$$
\begin{aligned}
& 1 \\
& \frac{15 \mathrm{jt}-\mathrm{X}}{15 \mathrm{jt}-5 \mathrm{jt}}: 5 \mathrm{jt} \leq \mathrm{X} \leq 15 \mathrm{jt} \\
& 0 \quad: X \geq 15 \mathrm{jt}
\end{aligned}
$$

( $\mu$ Pendapatan Sedang) :

$$
0 \quad ; \mathrm{X} \leq 10 \mathrm{jt} \text { atau } \geq 20 \mathrm{jt}
$$

$20-\mathrm{Xjt}: 10 \mathrm{jt} \leq \mathrm{X} \leq 20 \mathrm{t}$

$20 \mathrm{jt}-10 \mathrm{jt}$

$$
\begin{aligned}
& \text { ( } \mu \text { Pendapatan Tinggi) } \\
& 0 \quad ; X<15 \mathrm{jt}
\end{aligned}
$$$$
\underline{\mathrm{X}-15 \mathrm{jt}}: 5 \mathrm{jt} \leq \mathrm{X} \leq 15 \mathrm{jt}
$$

$$
25-15
$$

$$
: \therefore \geq 25 \mathrm{jt}
$$

\subsection{Variabel Pengeluaran}

Variabel pengeluaran merupakan variabel peengeluaran yang dikeluarkan oleh pemohon kredit. Dalam hal ini besaran pendapatan yang di keluarkan pemohon kredit dinilai berdasarkan rentan waktu 30 hari (1 bulan). Variabel pengeluaran dibagi menjadi tiga himpunan yaitu Rendah, Sedang, dan Tinggi

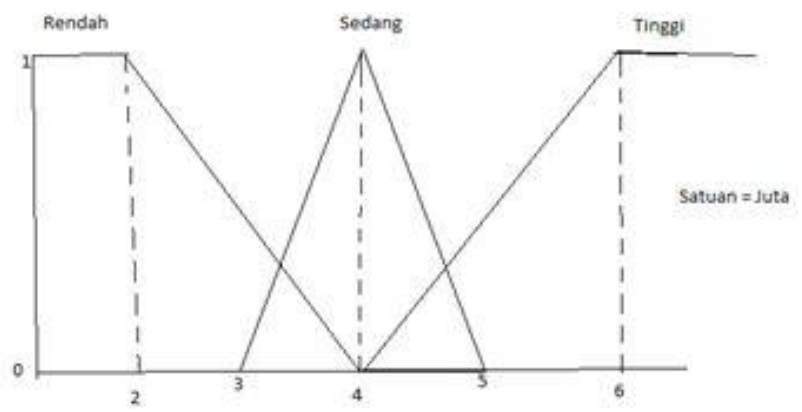

Gamber 3.2 Yariabel Input Pengeluaran

( $\mu$ Pengeluaran Rendah) :

$$
\begin{array}{ll}
1 & : \mathrm{Y}<2 \mathrm{jt} \\
4 \mathrm{Jt}-\mathrm{Y} & : 2 \mathrm{jt} \leq \mathrm{Y} \leq 4 \mathrm{jt}
\end{array}
$$

$4 \mathrm{jt}-2 \mathrm{jt}$

$$
0 \quad: \mathrm{Y} \geq 4 \mathrm{jt}
$$

( $\mu$ Pengeluaran Sedang) :

$0 \quad ; Y \leq 3$ atau $\geq 5$

5-Yjt $: 3 \leq \mathrm{Y} \leq 5$

\subsection{Variabel Jarak}

Variabel Jarak merupakan salah satu variabel yang menjadi pertimbangan Credit Analyst untuk menentukan apakah pemohon kredit dapat diberikan pinjaman atau tidak. Variabel jarak dibagi menjadi tiga himpunan yaitu Dekat, Sedang, dan Jauh.

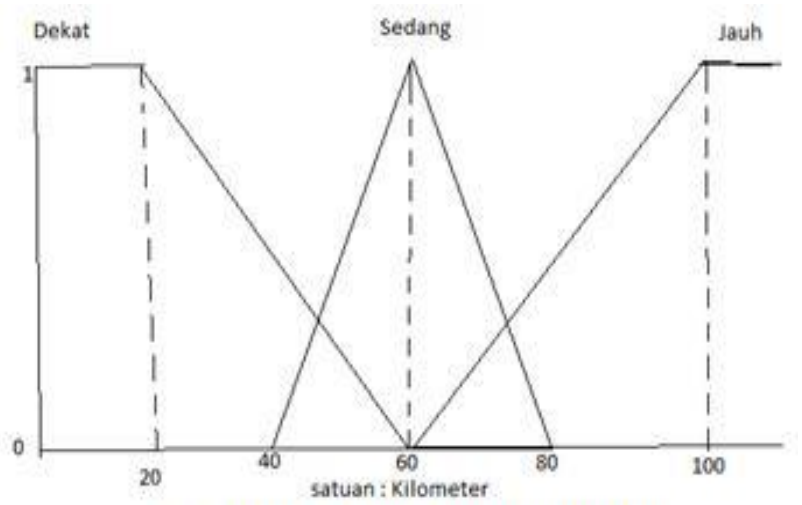

Gamber 3.3 Yariabel Input Jarak

\subsection{Variabel Jarak}

Variabel Usia merupakan salah satu variabel yang menjadi pertimbangan Credit Analyst untuk merekomendasikan kredit apakah dapat diberikan pinjaman atau tidak. Variabel usia dibagi menjadi 3 himpunan Fuzzy yaitu Remaja, Dewasa, Tua

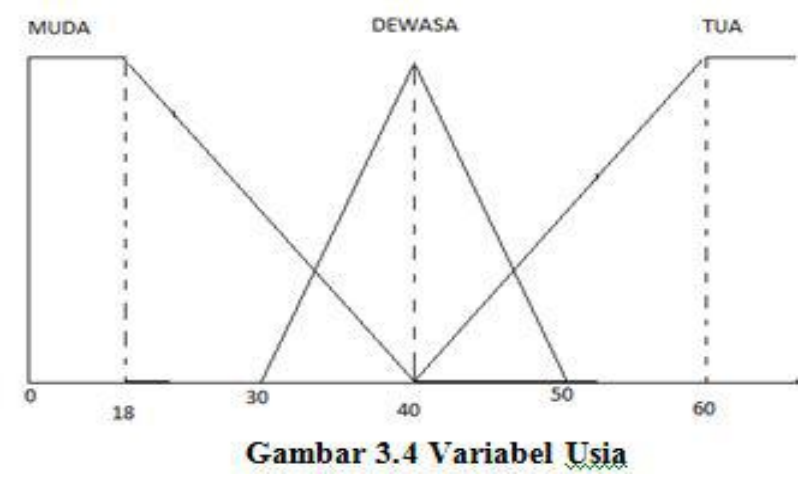

( $\mu$ Usia Muda) :

$$
\begin{array}{ll}
1 & ; X<18 \\
\frac{40-X}{40-18} & : 18 \leq X \leq 40 \\
0 & : X \geq 40 \\
\text { ( } \mu \text { Usia Dewasa) } & : \\
0 & ; X \leq 30 \text { atau } \geq 50 \\
\frac{50-X}{50-30} & : 30 \leq X \leq 50
\end{array}
$$




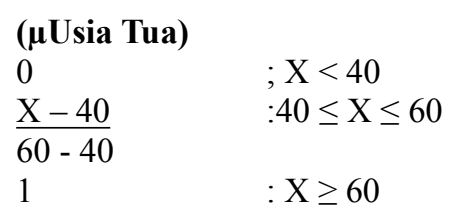

\subsection{Variabel Angsuran}

Variabel Input Angsuran merupakan variabel cicilan yang harus dibayar oleh debitur yang akan mengambil kredit. Variabel angsuran dibagi menjadi 2 himpunan Fuzzy Rendah dan Tinggi.

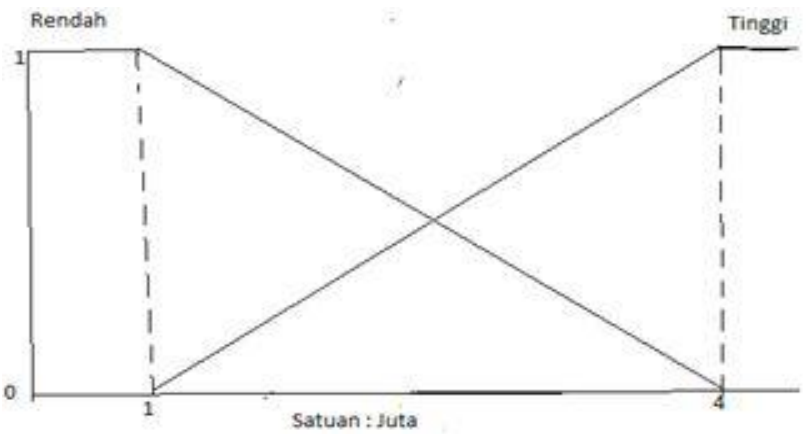

Gamber 3.5 Yariabel Input Angsuran
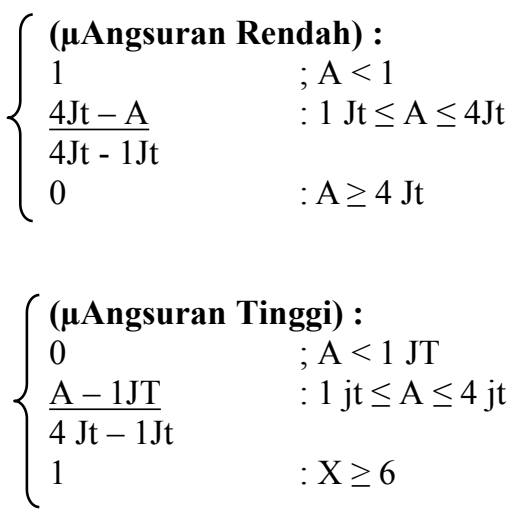

\section{Hasil dan Pembahasan}

\subsection{Contoh Kasus}

Jika Seorang Pemohon Kredit yang bekerja sebagai wiraswasta dengan rata-rata pendapatan 12 juta / bulan, dan mempunyai 1 orang istri 2 orang anak yang pengeluaran totalnya mencapai 3,5 Juta / bulan kini pemohon kredit berusia 34 tahun. Pemohon kredit sendiri berdomisili di Sidomulyo Lampung Selatan yang estimasi Jarak dari Rumah ke kantor adalah 50 KM, berapakah estimasi batas maksimal angsuran yang dapat diberikan kepada pemohon kredit. Dan tentukan berapa persen ratio angsuran tersebut. Langkah pertama mencari nilai ke anggotaan:

Nilai Keanggotaan Pendapatan.

$\mu$ PendapatanRendah $(12 \mathrm{jt})=(15 \mathrm{jt}-12 \mathrm{jt}) / 10 \mathrm{jt}=0.3$ $\mu$ PendapatanSedang $(12 \mathrm{jt})=(20 \mathrm{jt}-12 \mathrm{jt}) / 10 \mathrm{jt}=0.8$ $\mu$ PendapatanTinggi $(12 \mathrm{jt})=0$

Nilai Keanggotaan Pengeluaran.

$\mu$ PengeluaranRendah $(3.5 \mathrm{jt})=(4 \mathrm{jt}-3.5 \mathrm{jt}) / 2 \mathrm{jt}=0.25$ $\mu$ PengeluaranSedang $(3.5 \mathrm{jt})=(5 \mathrm{jt}-3.5 \mathrm{jt}) / 2 \mathrm{jt}=0.75$ $\mu$ PengeluaranTinggi $(3.5 \mathrm{jt})=0$

Nilai Keanggotaan Jarak

$\mu$ Jarak Dekat $(50 \mathrm{Km})=(60 \mathrm{~km}-50 \mathrm{~km}) / 40 \mathrm{~km}=0.25$

$\mu$ Jarak Sedang $(50 \mathrm{Km})=(80 \mathrm{~km}-50 \mathrm{~km}) / 40 \mathrm{~km}=0.75$ $\mu$ Jarak Jauh $(50 \mathrm{~km})=0$

\section{Nilai Keanggotaan Usia}

$\mu$ Usia Muda $(34$ thn $)=(40$ thn -34 thn $) / 22$ tahun $=0.27$ $\mu$ Usia Dewasa $(34 \mathrm{thn})=(50 \mathrm{thn}-34 \mathrm{thn}) / 20 \mathrm{t} \mathrm{hn}=0.8$ $\mu$ Usia Tua (34 Tahun) $=0$

Langkah kedua Menentukan basis / rule. Rule yang akan digunakan sebagai aturan untuk menentukan nilai himpunan Angsuran.

\begin{tabular}{|c|c|c|c|c|c|c|c|c|c|c|}
\hline No & \multirow{18}{*}{ IF } & Pendapatan & \multirow{18}{*}{ AND } & Pengeluaran & \multirow{18}{*}{ AND } & Jarak & \multirow{18}{*}{ AND } & Usia & \multirow{18}{*}{ THEN } & Angsuran \\
\hline $\mathrm{Rl}$ & & TINGGI & & TINGGI & & JAUH & & TUA & & RENDAH \\
\hline $\mathrm{R}_{2}$ & & TINGGI & & TINGGI & & JAUH & & DEWASA & & RENDAH \\
\hline $\mathrm{R}_{3}$ & & TINGGI & & TINGGI & & JAUH & & MUDA & & RENDAH \\
\hline R4 & & TINGGI & & TINGGI & & SEDANG & & TUA & & RENDAH \\
\hline RS & & TINGGI & & TINGGI & & SEDANG & & DEWASA & & TINGGI \\
\hline R6 & & TINGGI & & TINGGI & & SEDANG & & MUDA & & RENDAH \\
\hline $\mathrm{R} 7$ & & TINGGI & & INGGI & & DEKAT & & TUA & & RENDAH \\
\hline RS & & TINGGI & & TINGGI & & DEKAT & & DEWASA & & TINGGI \\
\hline Rg & & IINGGI & & TINGGI & & DEKAT & & MUDA & & TINGGI \\
\hline $\mathrm{R} 10$ & & TINGGI & & SEDANG & & JAUH & & TUA & & RENDAH \\
\hline R11 & & TINGGI & & SEDANG & & JAUH & & DEWASA & & TINGGI \\
\hline $\mathrm{R} 12$ & & TINGGI & & SEDANG & & JAUH & & MUDA & & RENDAH \\
\hline $\mathrm{R} 13$ & & TINGGI & & SEDANG & & SEDANG & & TUA & & RENDAH \\
\hline $\mathrm{R} 14$ & & TINGGI & & SEDANG & & SEDANG & & DEWASA & & TINGGI \\
\hline $\mathrm{R} 15$ & & IINGGI & & SEDANG & & SEDANG & & MUDA & & TINGGI \\
\hline $\mathrm{R} 16$ & & IINGGI & & SEDANG & & DEKAT & & TUA & & TINGGI \\
\hline R17 & & IINGGI & & SEDANG & & DEKAT & & DEWASA & & IINGGI \\
\hline
\end{tabular}

Untuk rule yang digunakan adalah 81 rule namun sebagai contoh hanya 17 rule yang ditampilkan. Setelah menentukan rule aturan, sekarang mencari nilai $\alpha$ predikat $_{1}-\alpha$-predikat 81 dan mencari nilai $Z_{n}$ menggunakan fungsi max dikarenakan kita akan mencari batas maksimal berdasarkan tabel basis aturan 3.2. Untuk mencari nilai $\alpha$ - Pred yaitu dari rule basis aturan di atas :

$$
\begin{array}{r}
\boldsymbol{\alpha}-\text { Pred }=\underset{\text { max }}{(\mu \text { Pendapatan }} \\
\cap \mu \text { Pengeluaran } \\
\cap \mu \text { Jarak } \cap \text { Usia })
\end{array}
$$

[R1] :IF Pendapatan TINGGI AND Pengeluaran TINGGI AND Jarak JAUH AND Usia TUA THEN Angsuran RENDAH

$\alpha$-Pred1 :Max ( $\mu$ Tinggi(12jt) $\cap \mu$ Tinggi(3.5jt) $\cap$ $\mu \operatorname{Jauh}(50 \mathrm{Km}) \cap \mu \mathrm{Usia}(34$ tahun $))$

$=\operatorname{Max}(0 ; 0 ; 0 ; 0)$

$=0$

Untuk mencari nilai $z 1$ lihat himpunan Angsuran RENDAH.

Z1 : $4-\mathrm{A} / 3=0==\quad \mathrm{z} 1 \rightarrow 4$

Terdapat nilai 0 pada variabel di atas dikarenakan tidak termasuk anggota himpunan sehingga nilainya 0 . Berikutnya kita hitung R2 - R81. 


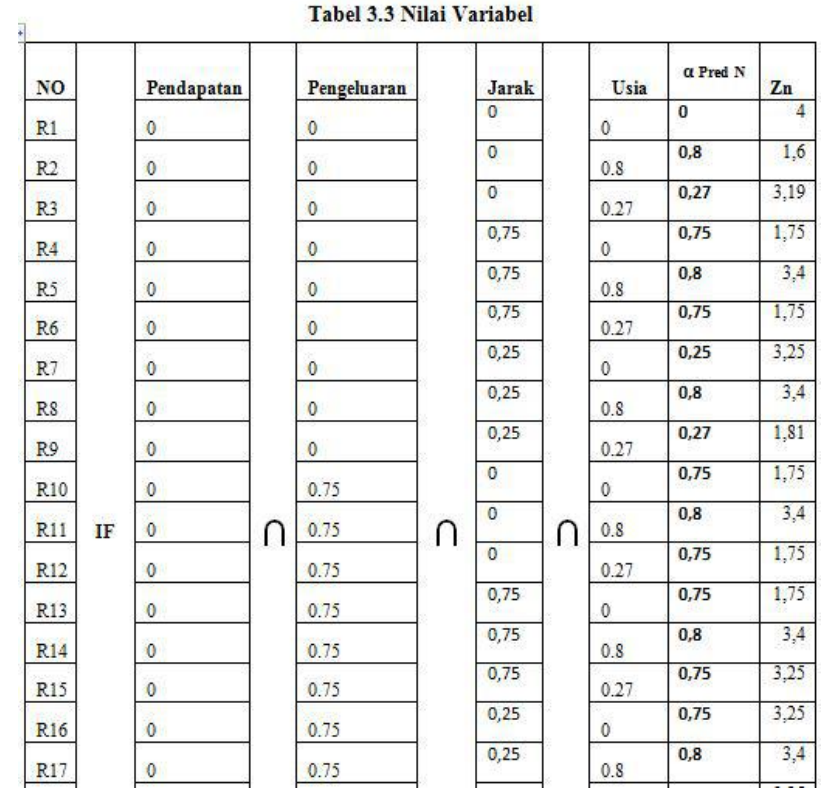

Nilai yang dicari dari R1 - R81, namun sebagai contoh hanya menampilkan sampai dengan R17. Nilai nilai yang terdapat di tabel di atas merupakan nilai keanggotaan dari masing masing variabel, nilai $\alpha$-predikat di dapat dari fungsi MIN tiap tiap baris aturan. Kemudian $Z_{1}-Z_{81}$ di dapat berdasarkan nilai terendah dari nilai himpunan masing masing baris aturan. Tahap berikutnya adalah tahap Defuzzyfikasi, tahap defuzzyfikasi, adalah tahap menentukan batas besaran nilai angsuran yang akan diterima pemohon kredit berdasarkan rule basis aturan yang sudah dibuat sehingga nanti diperoleh nilai rata-rata besaran angsuran yang di dapat. Untuk mencari nilai $Z$ (angsuran) dapat dicari dengan cara berikut:

$$
\mathrm{Z}=\frac{\alpha-\operatorname{Pred} 1 * \mathrm{Z} 1+\ldots .+\alpha \operatorname{Predn} * \mathrm{Zn}}{\alpha-\operatorname{Pred} 1+\ldots+\alpha-\operatorname{Predn}}
$$

Sehingga diperoleh hasil

$$
\mathrm{Z}=\frac{131,1849}{55,23}=2,375247
$$

Jadi pemohon kredit dapat diberikan pinjaman kredit dengan maksimal angsuran Rp 3.077659. Karena satuan yang digunakan adalah juta maka 2,375247*1000000= Rp 2.375.247

\subsection{Tampilan Sistem Login}

Pada Tampilan login ini terdapat user name dan password yang harus di isikan oleh user untuk bisa ke tampilan selanjutnya

\section{ClipanFinance}

\section{Silahkan Login ..}

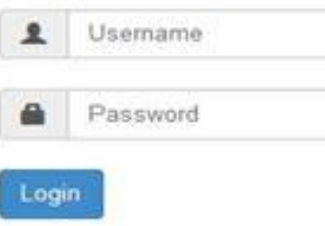

Gambar 4.1 Login

\subsection{Tampilan Data Pemohon Kredit}

Pada menu data nilai pemohon menampilkan data pemohon kredit yang telah diinputkan oleh data entry.

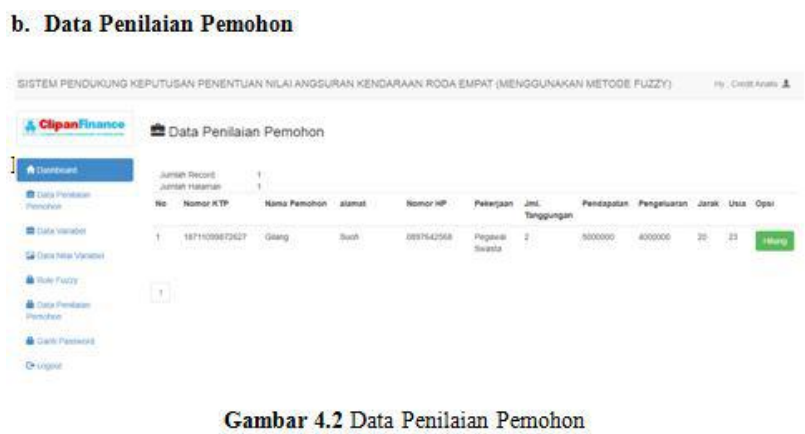

\subsection{Tampilan Nilai Variabel}

Menampilkan nilai nilai dari variabel variabel yang digunakan.

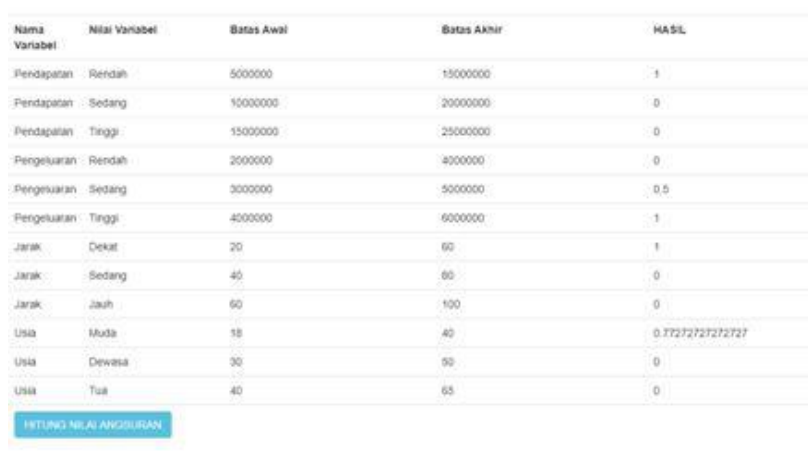

Gambar 4.3 Tampilan Nilai Variabel|

\subsection{Tampilan Rule Fuzzy}

Menampilkan menu data rule atau aturan dalam perhitungan 


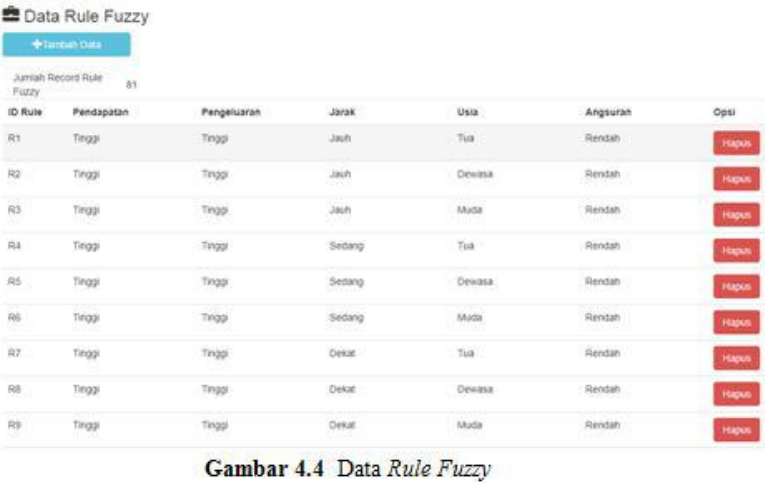

4.6 Tampilan Hasil Perhitungan

Data nilai pemohon ini menampilkan hasil perhitungan yang ada di menu credit analyst.

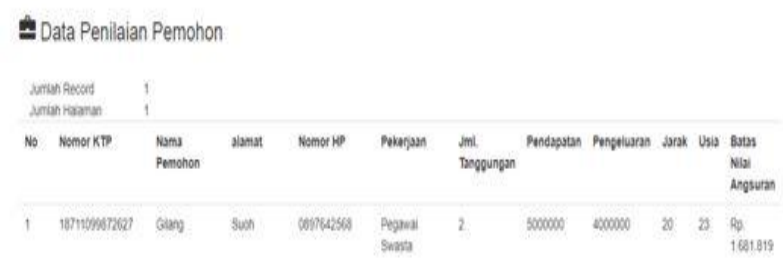

Gambar 4.5 Data Nilai Pemohon

\section{Kesimpulan}

Pada penelitian ini Fuzzy Tsukamoto ini dapat digunakan untuk menghitung batas kemampuan bayar pemohon kredit berdasarkan variabel ditetapkant dilihat dari batas besaran angsuran yang didapat dengan menjadikan acuan, variabel yang ada yaitu pendapatan, pengeluaran, jarak, usia. Untuk menguji Sistem Pendukung Keputusan ini menggunakan pengujian Black Box sedangkan untuk pengujian akurasi perhitungan menggunakan 60 data sample data yang sudah di approve untuk dibandingkan besaran nilai pemohon kredit. Dari hasil pengujian akurasi didapat hasil $83 \%$ tepat sehingga dapat disimpulkan bahwa sistem ini dapat membantu Credyt Analyst agar tidak salah dalam membuat rekomendasi keputusan yang dapat merugikan perusahaan.

\section{Daftar Pustaka}

[1] Sholihin, M., Fuad, N. and Khamiliyah, N. (2013) 'Sistem Pendukung Keputusan Penentuan Warga Penerima Jamkesmas Dengan Metode Fuzzy Tsukamoto', Sistem Pendukung Keputusan Penentuan Warga Penerima Jamkesmas Dengan Metode Fuzzy Tsukamoto, 5(2), pp. 501-506.

[2] Kaswidjanti, W., Aribowo, A. and Wicaksono, C. (2014) 'Implementasi Fuzzy Inference System Metode Tsukamoto Pada Pengambilan Keputusan Pemberian Kredit Pemilikan Rumah', Teknik Informatika, 10(2).

[3] Wantoro Agus, Priandika A.T., (2017), "Komparasi Perhitungan Pemilihan Mahasiswa Terbaik Menggunakan Metode Statistikklasik Dengan Logika Fuzzy (t Sukamoto Dan Mamdani) Studi Kasus : Stmik Teknokrat", Prosiding Seminar Nasional Teknologi Informasi, Mercubuana

[4] Mulyati, E. (2016) 'Kredit Perbankan'. Yogyakarta . Penerbit : REFIKA.

[5] Purnomo, H., Kusumadewi, S. (2010) 'APLIKASI LOGIKA FUZZY'. Yogyakarta. Penerbit : GRAHA ILMU.

[6] Irawan, P., Mazalisa, Z. and Panjaitan, F. (2015) 'Penerapan Metode Fuzzy Tsukamoto dalam Sistem Pendukung Keputusan Pemilihan Karyawan Terbaik', Student Colloquium Sistem Informasi \& Teknik Informatika (SC-SITI), pp. 135-138.

[7] Farouq, Kemal, S. M. (2014) 'Jurnal TeknikA Vol 6 No 2 September 2014', Penerapan Fuzzy Tsukamoto Dalam Pengangkatan Jabatan Pegawai Di Bkd Lamongan, 6(2), pp. 577-584.

[8] Logo, Jhonnry Frengky Bire, Agus Wantoro, and Erliyan Redy Susanto. "Model Berbasis Fuzzy Dengan Fis Tsukamoto Untuk Penentuan Besaran Gaji Karyawan Pada Perusahaan Swasta." Jurnal Teknoinfo 14, no. 2 (2020): 124-130.

[9] Imama, C. and Indriyanti, A. D. (2013) 'Nearest Neighbor Untuk Analisis Pemberian Kredit Di', Penerapan Case Based Reasoning Dengan Algoritma Nearest Neighbor Untuk Analisis Pemberian Kredit Di Lembaga Pembiayaan Chusnul, 2(1), pp. 11-21.

[10] Komariyah, S., Yunus, R. M. and Rodiyansyah, S. F. (2016) 'Logika Fuzzy dalam Sistem Pengambilan Keputusan Penerimaan Beasiswa', Jurusan Teknik Informatika Fakultas Teknik Universitas Majalengka, pp. 61-69. 